\title{
DINAMIKUS ÁRAZÁS ÉS STRATÉGIAI FOGYASZTÓK: KIHÍVÁSOK ÉS EGYÜTTMÚKÖDÉS A HOTELSZEKTORBAN
}

\section{DYNAMIC PRICING AND STRATEGIC CONSUMERS: CHALLENGES AND COOPERATION IN THE HOTEL SECTOR}

\author{
Fazekas Lajos Róbert ${ }^{1}$ \\ ${ }^{1}$ Vidékfejlesztés, Regionális Gazdaságtan és Turizmusmenedzsment Intézet, Gazdaságtudományi \\ Kar, Debreceni Egyetem, Ihrig Károly Gazdálkodás- és Szervezéstudományok Doktori Iskola, \\ Magyarország
}

\author{
Kulcsszavak: \\ mesterséges intelligencia \\ stratégiai fogyasztó \\ perszonalizáció \\ co-creation
}

\section{Keywords:}

artificial intelligence

strategic consumer

personalization

co-creation

\begin{abstract}
Összefoglalás
Néhány évtizede a dinamikus árazás varázsszónak számított a szállodaiparban. Mitikus tevékenység, amelynek bevezetésétől az üzemeltetők, tulajdonosok a jövedelmezőség drasztikus növekedését várták. Aztán kiderült szisztematikus adatgyưjtés, az erőforrások által megengedett, lehető legjobb informatikai háttér és szakember szükséges hozzá. Tényként kezelhetô, hogy aki kimaradt az lemaradt. Azonban aki beszállt, merre indult? Hová jutott? Önálló, sok irányzattal és kapcsolódási ponttal rendelkező tevékenységgé vált. Joggal nevezhetjük a szállodaipari yield management alapkövének. Áttekintésemben bemutatom, ma hol tart a szállodaipar a dinamikus árképzés területén. Az egyes irányzatok képviselőinek szeme előtt azonban egyetlen cél lebeg, a bevétel hosszútávú maximalizálása.

Abstract

A few decades ago dynamic pricing was a magic word in hotel industry. It was considered a mythic activity, and therefore, operators and owners expected that its introduction would result in a drastic increase in profitability. Then it turned out that it required systematic data collection, the best possible IT background in terms of the resources, and the presence of specialists. It can be accepted as a fact, that those who stayed out were left behind. However, which direction did those who joined take? What did they achieve? It became an independent activity with several trends and connection points. It can rightly be called the cornerstone of hotel industry yield management. In my review, I intend to show the present state of the hotel industry in the area of dynamic pricing. However, the representatives of each trend have a common goal: maximising their revenues in the long term.
\end{abstract}

\section{Bevezetés}

A dinamikus árazás a modern versenyképes piaci működés alapvető eszköze a fogyasztói társadalom szinte minden ágazatában. Különösen igaz ez a hotelszektorra, aminek speciális természete és magas technológiai adaptációja kiemelten fontossá teszi a dinamikus árazás felhasználását a sikeres hozzammenedzsment stratégiák kialakításában. Egyik legegyszerúbb megfogalmazásában a hozammenedzsment különböző árazási stratégiák alkalmazása a 
rendelkezésre álló nagymennyiségü adatmennyiséget felhasználva annak céljából, hogy a megfelelő termék, a megfelelő áron, a megfelelő fogyasztóhoz kerüljön [13]. Az új technológiák megjelenése és konzekvens elterjedése egy iparágon belül mindig magával vonja az uralkodó módszertanok lecserélődését vagy fejlődését is. A digitalizáció folyamatosan növekvő penetrációja a hotelszektor keresleti és kínálati oldalán egyaránt megköveteli a klasszikus dinamikus árazási módszerek továbbfejlesztését. Ennek oka mindkét esetben a rendelkezésre álló információs és kommunikációs technológiák (ICT) fejlődése, ami a hotelek vezetősége számára rendkívül alacsony költséggel és a korábbiaknál sokkal gyorsabban teszi lehetővé, hogy az árakat a fogyasztói bázis reakcióihoz igazítsák, a fogyasztók részéről pedig nagymennyiségű és célzott információforrást biztosít az egyes vásárlási döntések meghozásakor. A legújabb technológiák bevezetésére ugyanakkor fel kell készíteni a szálloda személyzetét is, amire jó megoldás lehet az élethosszig tartó tanulás különböző módszereinek alkalmazása [14]; [15].

A klasszikus dinamikus árazási modellek korábbi foglalások adatait használták, majd később ezekre építve adtak különböző előrejelzéseket, amik segítségével korrigálták egy adott szoba árát a foglalási időszak hossza vagy a már meglévő foglalások alapján. A modern rendszerek megpróbálnak további információs forrásokat is felhasználni az optimális ár meghatározására, mint a fogyasztói földrajzi elhelyezkedése vagy a foglalásra használt csatorna. A dinamikus árazási modellek elméleti végpontja, ha minden egyes individuális fogyasztóhoz személyre szabott árajánlatot alakítunk ki. Ez a koncepció elvezet a perszonalizáció fogalmához, ami a hotelszektor egyik legmeghatározóbb új irányzatává válhat a jövőben. A perszonalizáció nem csupán a személyreszabott árazási megoldásokat jelenti, hanem a vendégek egyre szorosabb bevonását saját élményeik létrehozásába és alakításába.

\section{Dinamikus árazás}

A dinamikus árazás a légiközlekedési szolgáltatóktól eredő árazási stratégia. A módszer eredetétől függetlenül szinte bármilyen piaci környezetben alkalmazható. Általános értelemben véve a felhasználás módját három fontosabb tényező határozza meg. Az első a rendelkezésre álló készlet újratölthetősége az adott értékesítési időszakban. Különböző árazási alternatívák állnak rendelkezésre fix mennyiségü készlet esetén - ahol a szolgáltatónak nincs lehetôsége az esetleges többletkeresletet új termékekkel kielégíteni - és újratölthető készletek esetében. A második meghatározó tényező a kereslet függetlensége. Különbséget kell tenni olyan termékek között, ahol a fogyasztók számára rendelkezésre álló információ befolyással van a fogyasztási hajlandóságra, és olyan szolgáltatások között, ahol az egyes vásárlások függetlenek egymástól. Végül maguk a fogyasztók jelentik az egyik legerősebb befolyásoló tényezőt abban az értelemben, hogy miopikus vagy megfontolt vásárlóként viselkednek. A miopikus fogyasztó egyetlen vásárlási feltétele, hogy a szolgáltatás vagy a termék költsége alatta legyen az általa meghatározott referenciaárnak, a megfontolt vagy stratégiai fogyasztók azonban figyelembe veszik az árak változásának lehetőségét és a lehető legjobb potenciális termékkosarat kívánják megszerezni a lehető legoptimálisabb áron [10].

A hotel szektor esetében a készlet fix, vagyis egy adott szoba egy adott napon csak egyszer értékesíthető. A modern árazási módszerek esetében sem a kereslet sem pedig a kínálat nem független, a már megtörtént foglalások, a korábbi évek előrejelzései és a még rendelkezésre álló készlet mind befolyásolják az adott szoba vagy szolgáltatás aktuális árát. Végül pedig a szállodák vendégei egyre inkább stratégiai gondolkodású fogyasztókká kezdenek válni, amit nagymértékben elősegítenek az internetes keresési lehetőségek. A hotelek továbbá számos különböző termékkel rendelkeznek (szobák kategóriája, mérete, többletszolgáltatások) vagyis a szakemberek kétszintű árazási problémával állnak szemben. Először is ki kell alakítaniuk egy kezdeti árat a szolgáltatásportfólió minden elemére, majd a dinamikus árazás segítségével igazítaniuk kell az árat különböző változók mentén [1].

Piaci szempontból nézve a klasszikus árazási stratégiák számos példáját láthatjuk Vives és munkatársainak munkájában (2018) [31], ahol többek között az alábbi megközelítésekről számolnak be: kereslet alapú árazás, költség alapú árazás, piaci penetrációt vagy lefölözést célzó árazás vagy a különböző promóciós céllal meghatározott időszakos árszintek egyes termékek esetében [34]; [24]. A dinamikus árazás témáját a szakirodalom négy főbb terület mentén vizsgálja. 
Az első és leglényegesebb kutatási kérdés az árváltozások okának elemzése. Beszélhetünk időben eltérő árakról, ami alatt azt értjük, hogy az egy adott termék egy adott időpontban egy bizonyos áron kapható, majd egy későbbi (vagy korábbi) időpontban már egy másik áron juthat hozzá a fogyasztó [14]. Ennek klasszikus példája a hotelek esetében a foglalási időszak közeledtével megfigyelhető árváltozások az egyes szobák esetében. Egy másik megközelítés a viselkedés alapú árazás, melynek lényege, hogy nagyobb hangsúly kerül magára a fogyasztóra és a fogyasztói viselkedés jellemzőire [5]. A viselkedés alapú árazás a fogyasztói bázis szegmentációját jelenti különböző attribútumok mentén. Minden hotel megkülönböztet többek között kikapcsolódási és üzleti céllal utazó személyeket, továbbá különösen a nagyobb hotelláncoknál jellemzőek a különböző hűségprogramok, amik a fogyasztók korábbi vásárlásai alapján biztosítanak potenciálisan alacsonyabb árakat, vagy csak a tagok számára igénybe vehető kedvezményeket. A stratégiai gondolkodású fogyasztók megjelenése tovább árnyalja ezt a képet, mivel ók aktívan figyelik a foglalási időszak folyamán megfigyelhető árváltozásokat ezért az ő esetükben több árazási modell együttes használata szükséges, ami egyaránt tartalmazhat áremeléseket és árcsökkenéseket is $[25]$.

Különösen a stratégia fogyasztók kapcsán válik jelentőssé a dinamikus árazással kapcsolatos vizsgálatok második csoportja, ami az ár méltányosságával foglalkozik. A dinamikus árazás során bekövetkező árkorrekciók, valamint a tény, hogy bizonyos szolgáltatások eltérő árakon érhetők el időbeli vagy a fogyasztó személyéhez köthető faktorok miatt, sérthetik a fogyasztók méltányosság érzetét, különösen akkor, ha ezeket az árváltoztatásokat nem költség, hanem profitorientált célúnak érzékelik [26]. A dinamikus árváltoztatással kapcsolatos fogyasztói reakciókat két okból fontos vizsgálni. Egyrészt az, hogy a fogyasztó mennyire érzékeli méltányosnak az adott árváltozást hatással van arra, hogy a tapasztalt ár mennyiben befolyásolja az adott fogyasztó termékkel kapcsolatos referencia árát [30], másrészt pedig negatív értékelést válthat ki a fogyasztóból maga a szálloda vagy szállodalánc felé, ami csökkentheti a jövőbeni fizetési hajlandóságot az adott szálloda szolgáltatásaiért vagy akár az adott fogyasztó elvesztését is eredményezheti [22].

A harmadik kutatási irány a készletgazdálkodás kihívásait vizsgálja. A szállodák célja a fogyasztó bázis teljes keresletének maximális kihasználása, ami azt jelenti, hogy számolni kell azokkal a fogyasztókkal is, akik a foglalási ablak későbbi szakaszaiban keresnek szobákat a várhatóan magasabb árak ellenére is. Készletgazdálkodási szempontból ez azt jelenti, hogy a rendelkezésre álló szobakapacitás egy része elérhető kell legyen a foglalási időszak minden szakaszában [35]. Chen és Schwartz (2008) [9] kimutatják, hogy a fogyasztók foglalási időpontjának meghatározása komplex problémává vált a stratégiai fogyasztók megjelenésével, ami nehezíti a készletgazdálkodással kapcsolatos optimális döntések meghozatalát is. Végül a negyedik kutatási irány visszatér magukhoz a hotelekhez és a dinamikus árazás infrastrukturális, emberi erőforráshoz köthető és szervezeti feltételeit vizsgálja [2]; [29].

\subsection{Dinamikus árazás: fejlett koncepciók}

Ahogy láthatjuk a dinamikus árazás legnagyobb kihívását a stratégiai gondolkodású fogyasztók jelentik. Ez a vendégcsoport, a technikai fejlődés eszközeivel felruházva, olyan viselkedésmintát mutat, ami két szempontból képvisel komoly kihívást a dinamikus árazás módszertana felé. A fó nehézséget a vásárlási szokások reaktivitása jelenti. Feltételezve, hogy egy adott hotel egy adott időpillanatban sikeresen meghatározza a rendelkezésre álló információk alapján a legoptimálisabb árazási döntéseket, ezek a döntések azonnal korrekcióra szorulnak amint a stratégiai fogyasztók érzékelik őket és az új körülményekhez igazítják vásárlási hajlandóságukat. Bizonyos értelemben mondhatjuk, hogy a dinamikus árazás párhuzamaként a fogyasztói oldalról megjelenik a dinamikus árérzékenység jelensége. A dinamikus árérzékenység vezet el a második problémához, mivel a klasszikus dinamikus árazási modellek már nem képesek megfelelően modellezni az új fogyasztói bázis viselkedését.

A komplexitás növekedésére adott válaszként a dinamikus árazás módszertanának többféle továbbfejlesztése is megjelent. Ezeknek közös pontja, hogy felismerik a stratégiai fogyasztók által képviselt új kihívásokat és ezekre reagálva gondolják újra vagy bővítik ki a meglévő modelleket.

$\mathrm{Az}$ első ilyen irányzatba azok a megoldások tartoznak, amik az informatikai és adatfeldolgozás területén megjelenő legújabb technológiákat kívánják beépíteni a dinamikus 
árazást segítő prediktív és döntéssegítő algoritmusokba. Ilyen például Zhang és munkatársainak modellje (2019) [36] akik egy három egységből álló modellt építenek fel. Munkájuk első része magát a hotelt és a versenytársakat elemzi, majd kialakít egy kezdeti alapárat. A második egység többek között az úgynevezett DeepFM módszert használja a foglalások előrejelzésére, ami egy neurális hálózatokat alkalmazó gépi tanulást felhasználó előrejelzési technika [12]. Zhangék dinamikus árazás modelljének harmadik egysége mély neurális hálózatok ${ }^{1}$ segítségével igazítja az árakat a fogyasztókról rendelkezésre álló információk, az alapár és a várható foglalások száma alapján. Az általuk használt modern módszertan képes pontosabb árkorrekciós javaslatokat tenni, ami növeli a hotelek hozammenedzsment rendszereinek hatékonyságát.

Egy további példa az új technológiák felhasználására Brunato és Battiti (2019) [3] munkája, akik gépi tanulás, intelligens heurisztikák és intelligens optimalizáció segítségével hoztak létre egy szimulátort. Az intelligens optimalizáció lehetséges döntések automatikus generálását jelenti a modellen belül. A modell segítségével szimulálni lehet az egyes árazási stratégiák mentén bekövetkező várható foglalási számokat és jövedelmezőséget, mindezt ráadásul rendkívül rövid időn belül. A szerzők megfogalmazás szerint „mindössze 15 perc kell a modell tanulási szakaszának végrehajtásához” [3], ami után rögtön használható az adott hotel adatbázisának elemzésére. Az ilyen programok egyik rendkívül nagy előnye az lehet a hozammenedzserek számára, ha saját szállodájuk vendégeinek adatait használják a szimulátor adatbázisaként, aminek segítségével előrejelzéseket kaphatnak különböző árazási alternatívák jövőbeni kimeneteleiről.

Ahogy láthatjuk ezek a fejlesztések valójában nem változtatnak a dinamikus árazás klasszikus megközelítésén, hanem magasan fejlett technológiai megoldások segítségével szélesítik a felhasználhatóság körét. A fejlesztések egy másik csoportja már úgy próbálja hatékonyabbá tenni az egyes árazási modelleket, hogy kibővíti a vizsgált faktorok körét. Möhring és munkatársai (2019) [18] munkájában áttekintést adnak a fejlett dinamikus árazási koncepciók ezen csoportjáról.

A különböző fogyasztói csoportokhoz igazított optimális szoba és szolgáltatásár meghatározásában hatékony segítség lehet a foglalási csatorna beépítése a dinamikus árazási modellbe. Ennek a koncepciónak az értelmében a vendégek különböző árakkal találkozhatnak, attól függően, hogy milyen csatornán foglalják le a szobákat. Az okostelefonok széles körü elterjedése kapcsán érdemes megjegyezni, hogy a különböző mobilapplikációkon keresztül történő vásárlás növeli a vásárlási hajlandóságot és ezáltal az ilyen applikációval rendelkező szolgáltatók jövedelmét is [33].

A különböző csatornákhoz tartozó különböző árak esetében felmerülhet a hotelek és az OTA-k együttmúködése között vizsgált árparitás kérdése (a témáról bővebben: [19]). Az árparitás körüli viták esetében is elmondható, hogy az árak különbözőek lehetnek két csatorna, például a hotel saját honlapja és az OTA foglalási felülete között, ugyanakkor lényeges különbség, hogy ebben az esetben a különböző árak oka, hogy valójában két különböző szolgáltatóról beszélünk. A dinamikus árazás csatorna alapú differenciája esetében egy szolgáltató általál kínált árak között jelentkezhet különbség az alapján, hogy milyen csatornán keresztül találkozik a vendég az adott ajánlattal.

A dinamikus árazási modellek további lehetséges fejlesztési iránya a földrajzi elhelyezkedés bevonása az árak kialakításába. Szolgáltatói oldalról nézve is kimutatható, hogy a fogyasztók ugyanazért a szolgáltatásért különböző árakat hajlandóak fizetni attól függően, hogy melyik országban található az adott hotel [23]. Fogyasztói szempontból ugyanakkor azt kell figyelembe venni, hogy a különböző országok eltérő jövedelemszinttel rendelkeznek, ami jelentős befolyással bír az ország lakosainak referencia áraira és fizetési hajlandóságára egy bizonyos szolgáltatással kapcsolatban [18]. A modern ICT csatornákon keresztül történő foglalások esetében könnyüszerrel megállapítható a vendégek forrásországa, ami lehetővé teheti az adott országról rendelkezésre álló információk alapján a kínált ár azonnali korrekcióját.

Möhringerék [18] további két trendet mutatnak be, ami eredményeik alapján megváltoztathatja a dinamikus árazás jelenlegi múködését. Az egyik ilyen az alapvető szolgáltatásokon (mint a szoba) túli komponensek dinamikus árazása. Jelenleg a többletszolgáltatások (például a wellness) legtöbbször egy fix árért vehetők igénybe, azonban

1 A mély neurális hálózat, több neurális háló széles és mély egymásra építését jelenti kis architektúrák mentén (forrás: https://www.sciencedirect.com/topics/engineering/deep-neural-network) 
elméleti szinten semmi akadálya nincs annak, hogy ezek a szolgáltatások is dinamikusan legyenek árazva különböző faktorok mentén. Ez a módszer ugyanakkor ismételten felveti a méltányosság kérdését. Figyelembe véve, hogy már az alapszolgáltatások dinamikus árazása is sértheti a fogyasztók egy részének méltányossági érzését, a módszer kiterjesztése a többletszolgáltatásokra további negatív reakciókat válthat ki. Válaszként szolgálhat erre például a dinamikusan kapcsolt áruk módszere, ahol a többletszolgáltatások különböző termékkosarak formájában kerülnek összekapcsolásra az alapvető szolgáltatásokkal és az így kialakított termékkosarak tartalmuk alapján fognak különböző árakkal rendelkezni [17].

A másik megfigyelhető trend valójában nem markáns változás. Ennek lényege olyan versenytársak vagy új piaci szereplők figyelése, akik valamilyen új piaci megközelítéssel jelentkeznek vagy egy korábban kevésbé hangsúlyos piaci szegmensre fókuszálnak. Példa erre a TRIPBAM, ami a már meglévő foglalások esetében kezdett el lehetséges olcsóbb alternatívákat keresni és értesíteni a fogyasztót amennyiben kisebb költséggel is megkaphatta ugyanazt a szolgáltatást [20]. A TRIPBAM és a hozzá hasonló szolgáltatók jelentősége, hogy automatizálják a stratégiai fogyasztók valamilyen jellemző viselkedését és könnyen hozzáférhető teszik olyan fogyasztók számára is, akik önmaguktól miopikus fogyasztónak minősülnének. A dinamikus árazási modelleknek ezeket a változásokat is be kell építeniük algoritmusaikba, mivel jelentős mértékben megváltoztathatják a modellezett piaci környezet jellemzőit.

Végül néhány gondolat erejéig érdemes szót ejteni a személyre szabott árazás gondolatáról. Elméleti értelemben a dinamikus árazás célja, hogy minél pontosabb és kisebb szegmensekre bontsa a teljes fogyasztói bázist és mindegyik csoporthoz megkeresse a hozzátartozó legoptimálisabb árazási szintet, amivel növeli a hotel jövedelmezőségét. Ennek értelmében a legmagasabb jövedelmezőség akkor érhető el, ha minden egyes fogyasztó esetében az adott individuumra külön határozzuk meg az árszintet. Az adatfeldolgozási és modellezési technológiák minden fejlődése ellenére ez egyelőre nem lehetséges, valamint számos jogi korlátozás (például GDPR) is komoly kihívásokat állítana a tényleges megvalósítás elé. Ugyanakkor a szakemberek egy csoportja azt is felismerte, hogy a stratégiai fogyasztók a méltányosság érzete miatt nem jól fogadnák a teljesen egyénre szabott árazási modelleket. Richards és munkatársainak (2016) [21] kutatása a kérdést vizsgálva azonban egy meglepő eredményt mutatott. A fogyasztók hajlandók voltak jelentős személyek közötti árkülönbségek elfogadására abban az esetben, ha lehetőségük volt az árak meghatározásában részt venni. Az elsőre kontraintuitív gondolat, hogy a fogyasztó részt vegyen az ár meghatározásában valójában nem is olyan megdöbbentő, ha figyelembe vesszük, hogy a modern fogyasztók vásárlási szokásai egyre szervesebb részét képezik a dinamikus árazási modelleknek és hogy a fogyasztók által generált tartalmak milyen jelentős hatással vannak egy hotel foglalásaira [27]. A hotelszektor vezető szakemberi felismerték, hogy a sikeres múködés egyik kulcskérdése a jövőben a fogyasztó szorosabb integrációja lesz a hotel müködésében. Ez a megközelítés hívta életre a fogyasztói élmény szempontjából történő perszonalizáció koncepcióját, valamint a valós időben történő, a fogyasztóval közös tartalomlétrehozás gondolatát.

\subsection{Személyreszabott élmények és közös tartalomgyártás}

A fogyasztókkal való együttmúködés a szolgáltatási vagy gyártási folyamat során nem újkeletű gondolat. A közös gyártás (angolul: co-production) már az 1980-as években megfigyelhető jelenség volt [8] azonban a fogyasztók ilyen jellegű bevonása az elkészült terméket helyezte a középpontba. A közös tartalomlétrehozás (angolul co-creation) a szolgáltatások és termékek alapvető újrafogalmazásának eredménye, ami a modern piaci társadalomban úgy nyilvánul meg, hogy a középpontba nem a késztermék, hanem maga a fogyasztói élmény kerül. A használat közbeni értékteremtés (angolul: value-in-use) fogalma a fogyasztási folyamat során létrehozott értéket és élményt jelenti, melynek létrehozásában jelentős szerepet játszik maga a fogyasztó is [6]. A co-creation és a használat közbeni értékalkotás tényleges megvalósulásának elengedhetetlen feltétele volt a technológiai fejlődés. Az okostelefonok a közösségi médiafelületek, valamint az egyre szélesebb körben terjedő integrált online hálózatok (Internet of Things - IoT) világában lehetőség van a fogyasztó minden korábbinál szorosabb bevonásába az általa igénybe vett szolgáltatás alakításába. Az új irányzat egyik kulcsfogalma a valós idejű reakció a fogyasztó igényeire. A nagy mennyiségű adatra épülő, technikai innovációk segítségével kialakított, és ezáltal a fogyasztókkal 
valós idejü interakciót lehetővé tevő megoldások a termék és árdifferenciáció mellett a versenyelőny harmadik forrásává kezdenek válni a szolgáltató szektor szereplői között [28]. A közös élményteremtés Buhalis és Sinarta (2019) [4] munkája alapján öt alapvető faktorra vezethető vissza, melyek az azonnaliság, a közös tartalomteremtés, az adatvezéreltség a fogyasztóközpontúság és az élményteremtés. Mindez a különböző közösségi média felületek és magasan képzett személyzet segítségével válik lehetségessé, akik képesek a megfelelő csatornákon keresztül kapcsolatba lépni a vendégekkel a lehető legrövidebb idő alatt. A közös tartalom létrehozás fogalmába tartozik a kiváló szolgáltatás színvonal nyomán megfogalmazott elektronikus szájbeszéd a fogyasztó részéről, ahogy a szálloda személyzetének segítségnyújtása is, amikor egy vendég valamilyen online felületen keresztül segítséget kér az esti programjának megszervezésében. A folyamat kulcstényezője a minél gyorsabb és minél személyreszabottabb reakció, amin keresztül maradandó érték teremtődik a vendég számára.

A co-creation ugyanakkor nem csak a fogyasztó számára jelent nyereséget. A vendégek bevonása saját élményeik megalkotásába a megélt szubjektív élményen túl pozitív hatással van a hotel brandjének értékére is [11]. Nem szabad ugyanakkor elfelejteni, hogy a túlzott perszonalizáció negatív hatással is lehet a fogyasztók élményére, többek között a döntési autonómia elvesztésének érzése miatt, valamint mivel a fogyasztók úgy érezhetik, hogy alternatív lehetőségektől eshetnek el az előre biztosított kész ajánlatlisták miatt [32]. A közös tartalomgyártás esetében is szükségesek olyan mediáló faktorok, (mint az észlelt rizikó, a transzparencia vagy a vendég bizalma a szálloda felé [11] feltérképezése, amik befolyásolhatják a vendégek által megélt élményt és a co-creationben való részvételi hajlandóságot.

Végül érdemes megemlíteni, hogy a közös tartalomteremtés fokozatos térnyerése ellenére egyenlőre még korlátozott mértékben figyelhető meg a szállodaiparban. Számos külső és belső tényező akadályozhatja a koncepció sikeres adaptációját egy szállodában, például különböző kulturális különbségek, a szálloda vezetőségének félelme a potenciális veszélyektől és költségektől, a személyzet nem megfelelő tréningje vagy a fogyasztó bizalmatlansága egy hotel vagy hotellánc felé, ami miatt nem hajlandó részt venni a közös tartalom létrehozásban [7].

\section{Összefoglalás}

A légiközlekedés szektorából induló dinamikus árazás gyors ütemben vált a hotelszektor meghatározó módszertanává. A gyors és széleskörű technikai adaptációval jellemezhető szállodaipar hatékony árazási szoftvereket és módszertant dolgozott ki, aminek azonban jelentős új kihívást állított az internet és ICT technológiák elterjedése a fogyasztók körében. A digitalizáció által biztosított új képességek birtokában a szállodák szolgáltatásait igénybe vevő vendégek egy csoportja elkezdett stratégiai fogyasztóként viselkedni, vagyis döntéseiket az egyre nagyobb mértékben rendelkezésre álló adatokra és megfigyelhető árazási trendekre kezdték alapozni. Az új fogyasztói viselkedés, valamint az értékesítési csatornák gyökeres megváltozása, többek között az OTA-k és az okostelefonok megjelenése, szükségessé tette a dinamikus árazási módszerek, valamint a fogyasztó és a szálloda viszonyának újragondolását. A fejlett dinamikus árazási modellek a legfejlettebb technológiai megoldások és a felhasznált adatok körének folyamatos bővítésével válaszolnak a digitalizálódó fogyasztói bázis új kihívásaira. Ezzel párhuzamosan az ICT technológiákra és a közösségi médiára építve a vendég bizonyos értelemben integrálásra kerül a szálloda múködésébe. A fogyasztó, mint saját élményének szerves formálója jelenik meg a hotel működésében és közösen törekednek a valós idejű és egyre személyre szabottabb szolgáltatások létrehozására. Ahogy a stratégiai fogyasztók köre folyamatosan bővül, a jövő egyik kulcskérdése az lehet, hogy hogyan tudják a szállodák egyre szorosabban integrálni a fogyasztókat a hotel müködésének egyre több területébe.

\section{Következtetés}

A modern dinamikus árazási modellek áttekintése néhány alapvetően fontos szálloda üzemeltetési kérdésre világít rá. Bevétel maximalizálás területén az előrelépés záloga a fejlett informatikai háttér, amelyek nemcsak a hardver és szoftver elemekben testesülnek meg, hanem azok informatikai üzemeltetésében és folyamatos fejlesztésében szerepet vállaló humánerőforrásban is 
(rendszergazda, szoftver fejlesztő). Fontos azzal is tisztába lenniük a hotel tulajdonosoknak, üzemeltetőknek, hogy a dinamikus árazások nem múködnek maguktól ehhez speciális szaktudással rendelkező, jól megfizetett munkavállalóra van szükség, aki sok esetben fontosabb láncszeme a munkavállalói csapatnak mint a szálloda igazgató. Sőt előfordul, hogy nehezebben is pótolható. Ugyanakkor a jó yield manager-nek meg azzal kell tisztába lennie, hogy a vendéget egyenrangúnak és partnernek kell tekintenie az árak kialakításánál, hiszen szimbiózisban élünk velük. Az interakció folyamatos. Mindez abból gyökerezik, hogy a potenciális vendégek egy része (fóleg a stratégiai fogyasztók) is hatalmas és rendkívül fejlett informatikai tudással és háttérrel rendelkeznek.

Fontos, hogy minden üzemeltető erőforrásaihoz mérten gondolkodjon a dinamikus árazási modellek bevezetése, alkalmazása során.

\section{Köszönetnyilvánítás}

A kutatás az EFOP3.6.3-VEKOP-16-2017-00007 - "Tehetségből fiatal kutató" - A kutatói életpályát támogató tevékenységek a felsőoktatásban. című projekt keretében valósulhatott meg.

\section{Irodalomjegyzék}

[1] Anderson, C. K. - Xie, X. (2016): Dynamic pricing in hospitality: overview and opportunities. International Journal of Revenue Management, 9(2-3), pp. 165-174

[2] Aubke, F. - Woeber, K. - Scott, N. - Baggio, R. (2014): Knowledge sharing in revenue management teams: Antecedents and consequences of group cohesion, International Journal of Hospitality Management, 41, pp. 149157

[3] Brunato, M. - Battiti, R. (2019). Combining intelligent heuristics with simulators in hotel revenue management, Annals of Mathematics and Artificial Intelligence, 88(1-3), pp. 71-90

[4] Buhalis, D. - Sinarta, Y. (2019): Real-time co-creation and nowness service: lessons from tourism and hospitality, Journal of Travel \& Tourism Marketing, 36(5), pp. 563-582

[5] Caillaud, B. - De Nijs, R. (2014): Strategic loyalty reward in dynamic price discrimination, Marketing Science, 33(5), pp. 725-742

[6] Chathoth, P. - Altinay, L. - Harrington, R. J. - Okumus, F. - Chan, E. S. (2013): Co-production versus cocreation: A process based continuum in the hotel service context, International Journal of Hospitality Management, 32, pp. 11-20

[7] Chathoth, P.K. - Ungson, G.R. - Harrington, R.J. - Altinay, L. - Okumus, F. - Chan, E.S.W. (2014): Conceptualization of value co-creation in the tourism context, in Prebensen, N., Chen, J. Samil, M. (szerk): Creating Experience Value in Tourism, CAB International kiadó ,Wallingford, pp. 33-47

[8] Chathoth, P. K., Ungson, G. R., Harrington, R. J., Chan, E. S. (2016): Co-creation and higher order customer engagement in hospitality and tourism services, International Journal of Contemporary Hospitality Management, 28(2), pp. 222-245

[9] Chen, C. C., Schwartz, Z. (2008): Timing matters: Travelers' advanced-booking expectations and decisions, Journal of Travel Research, $47(1)$, pp. 35-42

[10] Elmaghraby, W. - Keskinocak, P. (2003): Dynamic pricing in the presence of inventory considerations: Research overview, current practices, and future directions, Management science, 49(10), pp. 1287-1309

[11] González-Mansilla, Ó. - Berenguer-Contrí, G. - Serra-Cantallops, A. (2019): The impact of value co-creation on hotel brand equity and customer satisfaction, Tourism Management, 75, pp. 51-65

[12] Guo, H. - Tang, R. - Ye, Y. - Li, Z., \& He, X. (2017). DeepFM: a factorization-machine based neural network for CTR prediction. arXiv preprint arXiv:1703.04247. Elérhető online: $\underline{\text { https://arxiv.org/pdf/1703.04247.pdf }}$

[13] Kimes, S. E. - Wirtz, J. (2003): Perceived fairness of revenue management in the US golf industry, Journal of Revenue and Pricing Management, 1(4), pp. 332-344

[14] Kőmíves Péter Miklós - Dajnoki Krisztina (2016): Élethosszig tartó tanulás: híd a munkaerő-piac és a felsőoktatás között. Taylor Gazdálkodás- és Szervezéstudományi Folyóirat 2016/4. szám, No. 25. pp. 86-94. 
[15] Kőmíves Péter Miklós - Héder Mária - Dajnoki Krisztina (2018): Validation - A meeting point between higher education and the labour market? Cross-Cultural Management Journal 20:1 pp. 17-22.

[16] Larrieu, T. (2019): Pricing strategies in online market places and Price Parity Agreements: evidence from the hotel industry. mimeo https://www.researchgate.net/profile/Thomas Larrieu3/publication/334454759 Pricing strategies in online market places and Price Parity Agreements evidence from the hotel industry/links/5d2b91d4458515c11c31520e/Pricing-strategies-inonline-market-places-and-Price-Parity-Agreements-evidence-from-the-hotel-industry.pdf

[17] Li, W. - Hardesty, D. M. - Craig, A. W. (2018): The impact of dynamic bundling on price fairness perceptions, Journal of Retailing and Consumer Services, 4O, pp. 204-212

[18] Möhring, M. - Keller, B. - Schmidt, R. (2019): Insights into advanced dynamic pricing systems at hotel booking platforms. Information and Communication Technologies in Tourism 2019, pp. $265-277$. https://doi.org/10.1007/978-3-030-05940-8_21

[19] Nicolau, J. L. - Sharma, A. (2019): To Ban or not to ban rate parity, that is the question... or not?, International Journal of Hospitality Management, 77, pp. 523-527

[20] Piccoli, G. - Pigni, F. (2016): TRIPBAM: Leveraging Digital Data Streams to Unleash Savings. CAIS, 39,25 Elérhető online: https://pdfs.semanticscholar.org/e564/fo76b3a69b69604efo6742cf77b511befeed.pdf

[21] Richards, T. J. - Liaukonyte, J. - Streletskaya, N. A. (2016): Personalized pricing and price fairness, International Journal of Industrial Organization, 44, pp. 138-153

[22] Sahut, J. M. - Hikkerova, L. - Pupion, P. C. (2016): Perceived unfairness of prices resulting from yield management practices in hotels, Journal of business research, 69(11), pp. 4901-4906

[23] Sánchez-Pérez, M. - Illescas-Manzano, M. D. - Martínez-Puertas, S. (2019): Modeling hotel room pricing: A multi-country analysis, International Journal of Hospitality Management, 79, pp. 89-99

[24] Skripak, S.J. (2016): Fundamentals of Business, Pamplin College Kiadó, Virginai, Egyesült Államok

[25] Su, X. (2007): Intertemporal pricing with strategic customer behavior, Management Science, 53(5), pp. 726-741

[26] Tarrahi, F. - Eisend, M. - Dost, F. (2016): A meta-analysis of price change fairness perceptions, International Journal of Research in Marketing, 33(1), pp. 199-203

[27] Tsiakali, K. (2018): User-generated-content versus marketing-generated-content: Personality and content influence on traveler's behavior, Journal of Hospitality Marketing \& Management, 27(8), pp. 946-972

[28] Tuškej, U. - Podnar, K. (2018): Consumers' identification with corporate brands: Brand prestige, anthropomorphism and engagement in social media, Journal of Product \& Brand Management Online elérhető: https://www.emerald.com/insight/content/doi/10.1108/JPBM-05-2016-1199/full/html

[29] van der Rest, J. P. - Roper, A. - Wang, X. L. (2018): Why is a change of company pricing policy so hard to implement?, International Journal of Hospitality Management, 69, pp. 30-40

[30] Viglia, G. - Mauri, A. - Carricano, M. (2016): The exploration of hotel reference prices under dynamic pricing scenarios and different forms of competition, International Journal of Hospitality Management, 52, pp. 46-55

[31] Vives, A. - Jacob, M. - Payeras, M. (2018): Revenue management and price optimization techniques in the hotel sector: A critical literature review, Tourism Economics, 24(6), pp. 720-752

[32] Volchek, K. - Law, R. - Buhalis, D. - Song, H. (2019): The Good, the bad, and the ugly: Tourist perceptions on interactions with personalised content, e-Review of Tourism Research, 16(2-3), pp. 62-72

[33] Wang, R. J. H. - Malthouse, E. C. - Krishnamurthi, L. (2015): On the go: How mobile shopping affects customer purchase behavior, Journal of Retailing, 91(2), pp. 217-234

[34] Wang, X. L. - Yoonjoung, Heo C. - Schwartz, Z. - Legohérel, P. - Specklin, F. (2015): Revenue management: Progress, challenges, and research prospects, Journal of Travel \& Tourism Marketing, 32(7), pp. 797-811

[35] Weatherford, L. R. - Bodily, S. E. (1992): A taxonomy and research overview of perishable-asset revenue management: Yield management, overbooking, and pricing, Operations research, 4O(5), pp. 831-844

[36] Zhang, Q. - Qiu, L. - Wu, H. - Wang, J. - Luo, H. (2019): Deep Learning Based Dynamic Pricing Model for Hotel Revenue Management, In 2019 International Conference on Data Mining Workshops (ICDMW) pp. 370-375 